\title{
Comparison of satellite imagery and infrared aerial photography as vegetation mapping methods in an arctic study area; Jameson Land, East Greenland
}

\author{
ANDERS MOSBECH and BIRGER U. HANSEN
}

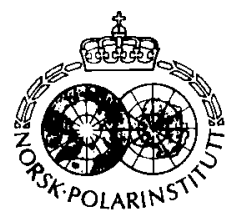

\begin{abstract}
Mosbech, A. \& Hansen, B. U. 1994: Comparison of satellite imagery and infrared aerial photography as vegetation mapping methods in an arctic study area; Jameson Land, East Greenland. Polar Research 13, $139-152$.

The two methods suited for mapping the vegetation of remote inaccessible terrain were compared in terms of their ability to reproduce and distinguish predefined vegetation classes, the appropriateness of their different spatial resolutions to the same end, and their cost-effectiveness. The study was carried out in Jameson Land, East Greenland $\left(70^{\circ} 30^{\prime} \mathrm{N}\right.$ to $\left.72^{\circ} \mathrm{N}\right)$. The vegetation had previously been classified and mapped by the use of false colour infrared aerial photos in the period 1982-86. The resultant vegetation maps had been drawn on aerial photo overlays at a scale of $1: 25,000$.

SPOT data from 8 September 1986 and Landsat TM data from 10 August 1987 were used. A supervised classification of the combined satellite data was made using a maximum likelihood algorithm. A vegetation map was produced which accurately plotted 9 of the dominant vegetation classes and 4 non-vegetation classes. The two mapping methods were then compared. The satellite-based method was found to be inadequate for the mapping of vegetation classes which occur in very small vegetation patches. The photobased mapping had better potential to map these vegetation classes because aerial photos have a higher spatial resolution than the satellite data. Small patches of herb slopes were selectively pinpointed in the photo-based mapping process. As the dominant vegetation types were, however, plotted in less detail, the photo-based mapping generally produced larger vegetation units with a more homogeneous and less complex texture than the satellite-based method.

Of the two methods, the satellite-based method was by far the more cost-effective. Satellite data were less expensive to obtain and process than aerial photos and time-consuming interpretation was eliminated. Both methods require detailed ground-truthing, but the satellite-based method requires less so due to the objective classification procedure. Overall, the satellite-based method seems advantageous for vegetation mapping in large remote areas. However, the satellite data still lacks the resolution to map all the important cover classes of the fine-scaled arctic tundra vegetation mosaic. Therefore purpose-specific adaptation of cover classes and manual augmentation may be necessary.
\end{abstract}

A. Mosbech, Greenland Environmental Research Institute, Tagensvej 135, DK-2200 Copenhagen N, Denmark; B. U. Hansen, Institute of Geography, University of Copenhagen, Øster Voldgade 10, DK-1350 Copenhagen K, Denmark.

\section{Introduction}

In 1982, the Greenland Environmental Research Institute initiated a number of background studies in Jameson Land, East Greenland, prior to a planned oil exploration in the area. The studies allowed a fundamental assessment of the vulnerability of important biological resources in the area to be made. The findings are being used to enforce regulations or codes of conduct so as to minimize the impact of the oil exploration activities.

A major task of the background study program was to classify and map the vegetation (Bay \& Holt 1986). Other studies have proved the sensitivity of various vegetation types to wear of vehicles (Holt \& Bay 1983), and which vegetation types were important to geese (Madsen \& Mortensen 1985) and muskoxen (Thing et al. 1987).

Vegetation mapping was introduced in 1982. At that time the spatial resolution of the available satellite data was inadequate for localizing important vegetation types in the very patchy vegetation mosaic. The mapping, which was completed in 1986 (Bay \& Holt 1986), was conducted using false colour infrared aerial photos and groundtruthing (in this paper called photo-based vegetation mapping).

Since 1982 , the quality of the satellite data available for vegetation mapping has improved considerably. It is now possible to buy multispectral data with a spatial resolution of 
$20 \times 20 \mathrm{~m}$. Therefore the primary purpose of this study was to test the satellite data as a tool for vegetation mapping and make a comparison with the mapping that had been previously conducted using false colour infrared aerial photos.

This paper describes the results achieved by vegetation mapping using SPOT and Landsat TM data versus false colour infrared aerial photos. The results are compared with regard to spatial resolution, the ability to distinguish predefined vegetation types, and the time/cost factors involved in the production of vegetation maps.

\section{Study area}

Jameson Land is a peninsula comprising approximately $10,000 \mathrm{~km}^{2}$ located to the north of the Scoresby Sund $\left(70^{\circ} 30^{\prime} \mathrm{N}\right.$ to $72^{\circ} \mathrm{N}$ ) (Fig. 1). The area is characterized by its relatively luxuriant vegetation in the lowland which forms the basis for an important population of muskoxen and moulting and breeding geese (Thing et al. 1987; Boertmann et al. 1992; Madsen \& Mortensen 1985; Boertmann 1991; Mosbech \& Glahder 1990).

Jameson Land slopes gradually from a mountain range in the northeast $(500-1000$ m.a.s.l) towards the coast. It is dissected by several valleys and deep canyons. The bedrock consists of Jurassic sediments, mainly sandstone. Quarternary deposits cover the bedrock in most places. In a $10 \mathrm{~km}$ broad belt along the western coastal zone, marine deposits predominate up to $80-100 \mathrm{~m}$ a.s.1. Inland a fairly thin and even till covers most of the bedrock surface. The western coastal zone and the western lowlands, known as Heden (0$200 \mathrm{~m}$.a.s.l.) is the main study area. Heden is a rather flat inland tundra dotted with small lakes and ponds. It is traversed by numerous stream gullies which are often asymmetric, with a steep southfacing side and a more gently sloping northfacing side. This shape is probably due to permafrost conditions. In several areas the deposits are very coarse as they have been eroded and weathered out of the loosely consolidated Jurassic sandstone.

The predominant vegetation type on Heden is continuous dwarf scrub heath, while graminoid fens occur in areas with wet soil. Snowbed and herb slope vegetation are found on southfacing slopes with sufficient water supply throughout the summer supplied from melting upslope snow- drifts. Along the western coast, fine-grained winddeposits forms dunes and there are a few' salt marshes. The more elevated eastern part is dominated by areas with sparse vegetation or bare ground.

Jameson Land is situated on the boundary between the high arctic and low arctic regions of East Greenland. The coastal zone and the eastern elevated areas are high arctic with mean air temperatures below $5^{\circ} \mathrm{C}$ in the warmest month (July), while the intervening central areas have mean air temperatures above $5^{\circ} \mathrm{C}$ in the warmest month (July). The coastal zone has a precipitation between $500-600 \mathrm{~mm}$, while the central areas are more continental with an annual precipitation between $300-400 \mathrm{~mm}$. Generally the $\mathrm{pH}$-values of the soils increase along the precipitation gradient, with $\mathrm{pH}$-values around 5.5 in the humid areas and 6.5 in the dry areas.

Strong northerly winds during the winter season redistribute the snow cover. On the southfacing slopes of hills and in drainage systems the snow accumulates, while the snow cover on the windswept northfacing slopes is either missing or very thin. The main snow-melt is in early June, while permanent snow cover is usually established within the last two weeks of September (Hansen \& Mosbech 1994 this volume).

The growing season starts in the beginning of June and ends in the beginning of September, with the peak in green biomass occurring early in August. However there are great differences in the growing seasons of different vegetation types because of differences in snow cover, water supply and soil water storage.

\section{Materials and methods}

\section{Photo-based mapping}

The false colour infrared aerial photo-based vegetation mapping of Jameson Land has been described by Bay \& Holt (1986). During photoflights in July 1982, 1250 pictures were taken covering all of Jameson land. A Kodak 2443, false colour infrared film was used. This film type is extra sensitive in the near infrared part of the spectrum, making it suitable for distinguishing between different vegetation types and soil moisture conditions. In the four growing seasons of 1982-86, vegetation analysis and ground-truthing were conducted in the field at 16 sites using the 


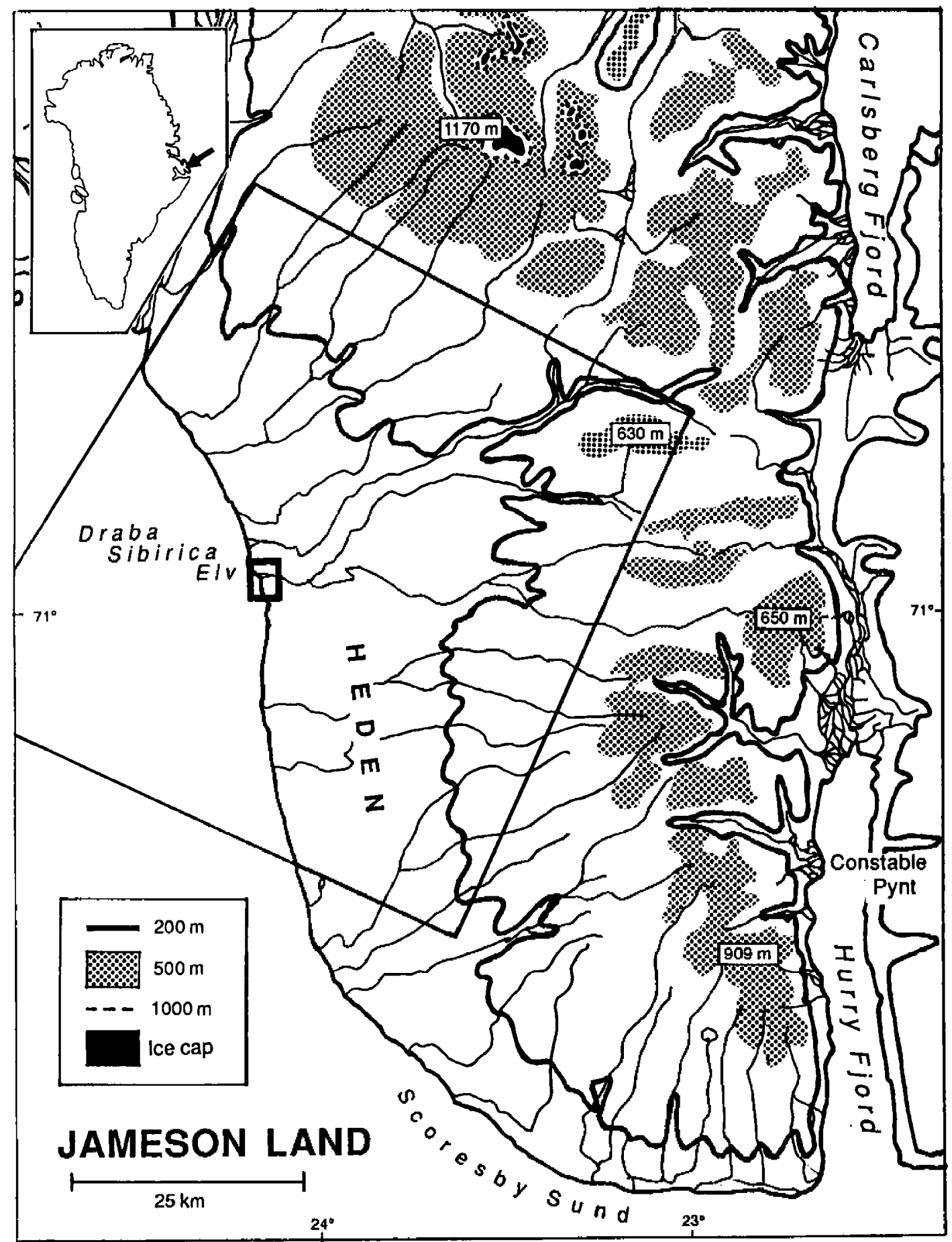

Fig. 1. The Jameson Land peninsula, East Greenland. The small box indicates the area mapped in Fig. 3. The large box indicates the area covered by both satellite images and mapped in Fig. 4. 
false colour infrared aerial photos as initial base maps.

The vegetation was classified after detailed knowledge had been obtained on the association, coverage, frequency and distribution of plant species in the terrain in relation to topographic, edaphic and local climatic factors. In the classification by Bay \& Holt (1986), based on Kar- markova \& Webber (1980), there are five main vegetation classes: fen (marsh), grassland, scrub heath, copse and snowbed. These are subdivided into 14 vegetation classes; in addition there are four non-vegetation classes (Table 1).

Vegetation maps were made manually using overlays of the aerial photos. Because the aerial photos had not been geometrically corrected and

Table 1. Cover classes in the photo-based mapping giving key species and topographic and moisture conditions (translated from Bay \& Holt 1986).

\begin{tabular}{|c|c|c|c|}
\hline Code & $\begin{array}{l}\text { Vegetation } \\
\text { class }\end{array}$ & $\begin{array}{l}\text { Key } \\
\text { species }\end{array}$ & $\begin{array}{l}\text { Topographic and } \\
\text { moisture conditions }\end{array}$ \\
\hline M1 & Fen & $\begin{array}{l}\text { Eriophorum scheuchzeri, Carex saxatilis, } C \text {. } \\
\text { rariflora, } C \text {. stans }\end{array}$ & $\begin{array}{l}\text { Level ground by water- } \\
\text { courses, lakes and ponds, } \\
\text { wet soil }\end{array}$ \\
\hline M2 & Hummocky fen & $\begin{array}{l}\text { Eriophorum triste, Ranunculus sulphureus, } \\
\text { Arctagrostis latifolia }\end{array}$ & Depressions and sloping terrain, wet soil \\
\hline G1 & Grassland & $\begin{array}{l}\text { Calamagrostis neglecta, Poa pratensis, } \\
\text { Arctagrostis latifolia, Polygonum viviparum }\end{array}$ & Level and sloping terrain, wet soil \\
\hline G2 & Salt marsh & $\begin{array}{l}\text { Carex subspathacea, Puccinellia phryganodes, } \\
\text { Stellaria himifusa }\end{array}$ & Level terrain by the coast, wet soil \\
\hline $\mathbf{H} 2$ & Herb slope & $\begin{array}{l}\text { Taraxacum spp., Hieracium alpinum, } \\
\text { Rhodiola rosea, Gentiana spp. }\end{array}$ & $\begin{array}{l}\text { Southfacing slopes down- } \\
\text { slope persistent snowbeds, } \\
\text { humid soil }\end{array}$ \\
\hline H3 & $\begin{array}{l}\text { Moist dwarf } \\
\text { scrub, coverage: } \\
>75 \%\end{array}$ & $\begin{array}{l}\text { Vaccinum uliginosum, Betula nana, Cassiope } \\
\text { tetragona }\end{array}$ & Level and sloping terrain, humid soil \\
\hline H4 & $\begin{array}{l}\text { Dry dwarf scrub, } \\
\text { coverage: } 25- \\
75 \%\end{array}$ & $\begin{array}{l}\text { Cassiope tetragona, Vaccinium uliginosum, } \\
\text { Betula nana }\end{array}$ & Level and sloping terrain, humid - dry soil \\
\hline H5 & $\begin{array}{l}\text { Dry, sparse } \\
\text { dwarf scrub } \\
\text { coverage: }<25 \%\end{array}$ & $\begin{array}{l}\text { Dryas octopetala, Betula nana, Vaccinium } \\
\text { uliginosum }\end{array}$ & Level and sloping terrain, dry soil \\
\hline H7 & Fell-field & $\begin{array}{l}\text { Dryas octopetala, Arctostaphylos alpina, Salix } \\
\text { arctica }\end{array}$ & $\begin{array}{l}\text { Wind-exposed sites and patterned dry - wet } \\
\text { soil }\end{array}$ \\
\hline H8 & Sand dune & $\begin{array}{l}\text { Dryas octopetala, Arctostaphylos alpina, Salix } \\
\text { arctica }\end{array}$ & Sandy wind-exposed sites, dry soil \\
\hline $\mathrm{T}$ & Copse & $\begin{array}{l}\text { Salix arctica, Potentilla crantzii, Stellaria } \\
\text { edwardsii }\end{array}$ & $\begin{array}{l}\text { Southfacing slopes and level terrain, humid } \\
\text { soil }\end{array}$ \\
\hline$\$ 1$ & Early snowbed & $\begin{array}{l}\text { Salix arctica, S. herbacea, Sibbaldia } \\
\text { procumbens, Carex scirpoidea }\end{array}$ & $\begin{array}{l}\text { Southfacing slopes on humid soil, early } \\
\text { melting of snow }\end{array}$ \\
\hline S2 & Late snowbed & $\begin{array}{l}\text { Salix arctica, Luzula confusa, Carex } \\
\text { lachenalii, Oxyria digyna }\end{array}$ & $\begin{array}{l}\text { Sloping and level terrain, wet soil, late } \\
\text { melting of snow }\end{array}$ \\
\hline S3 & Willow-snowbed & $\begin{array}{l}\text { Salix arctica, Carex bigelowii, Polygonum } \\
\text { viviparum }\end{array}$ & $\begin{array}{l}\text { Level or slightly sloping terrain, intermediate } \\
\text { melting of snow }\end{array}$ \\
\hline
\end{tabular}

Non-vegetation cover classes

Il Bare ground

I4 River

I5 Snow and ice

L Lake and pond 
to minimize the oblicity of the aerial photo, only the central parts of the overlapping photos were used. The vegetation types were identified on the aerial photos and drawn on the overlay. In areas with no ground-truthing, the vegetation type was interpreted from the aerial photo. Stereoscopic terrain analysis was used to help in the delineation of snowbed and herb slope vegetation on the southfacing slopes of hills and drainage systems.

\section{Satellite-based mapping}

Most satellites have sensors within the visible (VIS, 0.4-0.75 $\mu \mathrm{m}$ ) and near-infrared (NIR, 0.75$1.3 \mu \mathrm{m})$ wavebands because they are designed for vegetation monitoring. Fig. 2 illustrates reflectance curves typical of surfaces in eastern Greenland. Within the visible region, a typical vegetation reflectance curve will show strong absorption by the photosynthetic pigments at around 0.48 and $0.68 \mu \mathrm{m}$, while reflectance of green light is evident at 0.52 to $0.60 \mu \mathrm{m}$. The NIRwaveband is characterized by high reflectance and low absorption and is affected considerably by internal leaf structure.

Of particular importance to vegetation mapping has been the development of vegetation or greenness indices such as the normalized difference vegetation index NDVI (= (NIR - VIS)/
(NIR + VIS)). The ratio enhances vegetation and reduces variations caused by changes in irradiance which varies as a function of solar elevation. Clouds, water and snow reflect more in the VIS than in the NIR, so for these features the NDVI is negative. Rock and bare soil reflect similarly in both bands, so their vegetation indices are near zero. As for vegetation, NDVI ranges from 0.1 to 0.9 ; the higher values are associated with greater density and greater greenness of the plant canopy. Using reflectance data from Fig. 2, the NDVIvalues for the green surfaces of White Arctic Bellheather (Cassiope tetragone), Arctic Blueberry (Vaccinium uliginosum) and Arctic Cotton-grass (Eriophorum scheuchzeri) increase from 0.57 to 0.68 , which indicates an increasing vegetation coverage of the soil and an increasing biomass. Most wet areas are dominated by green mosses which have a reflectance curve very similar to the green luxuriant cotton grass, so the mosses will just emphasize the luxuriant areas during the vegetation monitoring.

The leaves of the Arctic Blueberry turn red after the first frost, but the low reflection in the 0.4 to $0.5 \mu \mathrm{m}$ range (Fig. 2) indicates some photosynthetic activity albeit reduced. For arctic blueberry the first frost causes a drop in the NDVI-value from 0.63 to 0.40 .

The reflectance curve for the bare ground (Fig.

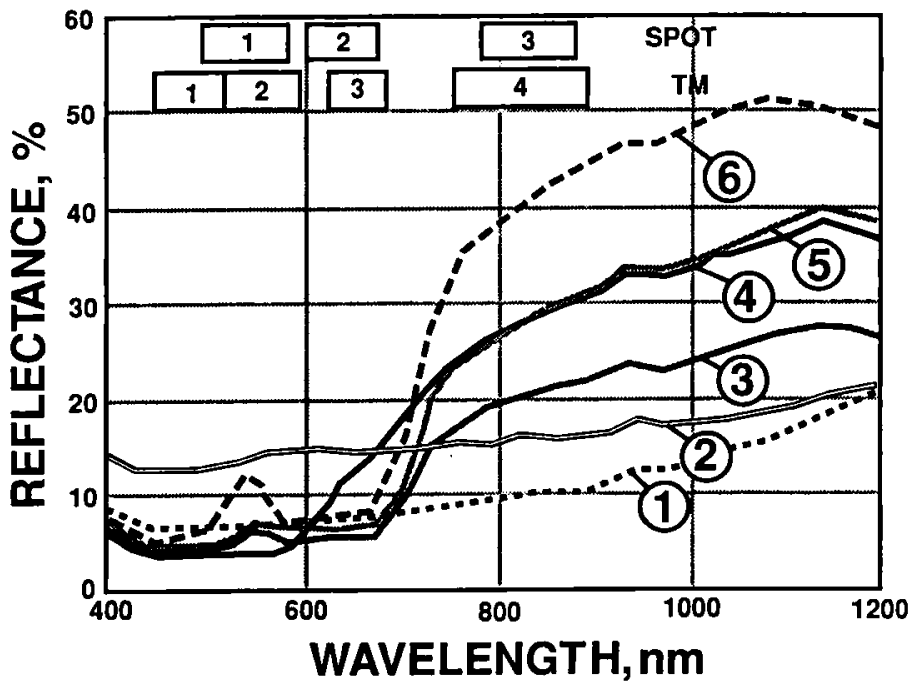

Fig. 2. Reflectance spectra of different surfaces based on ground measurements in East Greenland: $1=$ organic crust; 2 = bare ground; 3 = white arctic bell-heather; 4 = arctic blueberry, red; $5=$ arctic blueberry, green; $6=$ arctic cottongrass) (data from $B$. U. Hansen in prep.). Wavelengths for SPOT and Landsat TM bands are given at the top of the figure. 
2) on a wind-exposed ridge is almost level with the relative high values of the VIS-band so the surface appears as a bright surface in contrast to patches of unvegetated ground in the dry dwarf scrub heath which is covered by organic crust (consisting of prothallus of algae and lichens). The reflectance curve for this surface increases slightly towards the NIR-band, in the same way as the sparse cover of green vascular plants.

Recent advances in remote sensing technology present new opportunities and challenges for researchers working in remote areas. Vegetation and habitat mapping using the Landsat Multispectral Scanner (MSS), with a spatial resolution of $80 \times 80 \mathrm{~m}$ has been conducted in arctic Alaska (Walker \& Acevedo 1987), northern Canada (Thompson et al. 1980), Spitsbergen (Ødegaard \& Øritsland 1980) and Greenland (Folving 1986). Landsat Thematic Mapper (TM) data, with improved spatial $(30 \times 30 \mathrm{~m})$ and spectral $(7$ bands) as well as superior radiometric resolution, have been used to map muskox and bison habitats in Canada (Ferguson 1991; Matthews 1991) and reindeer habitats on Svalbard (Spjelkavik \& Elvebakk 1987) and in northern Norway (Johansen \& Tommervik 1990). In 1986, a High Resolution Visible (HRV) sensor was on board the Système Pour l'Observation de la Terre (SPOT) when it was launched. In multispectral mode, the SPOT sensors record spectral data from ground cells of $20 \times 20 \mathrm{~m}$, but unfortunately only in three bands. With a repeated coverage of 4 (off-nadir viewing) to 26 days (direct vertical viewing) at arctic latitudes, SPOT satellite data facilitate the possibility of cloud-free scenes and provide an excellent monitoring capability. SPOT data have been used for muskox habitat monitoring in Canada (Pearce 1991) and in Greenland (Olesen 1990), and for mapping arctic tundra vegetation in Alaska (Stow et al. 1989).

Initially the digital data of a cloud-free SPOT overpass on 8 September 1986 were analysed using the CHIPS-system (Holm et al. 1988). The SPOT data are from the arctic autumn at the end of the growing season when graminoides and deciduous shrubs have turned yellow or red and snow cover is usually underway, so the data were expected to be of limited use. However, the data were available and there was no snow cover in this image from 1986. It was later decided to extend and improve the classification by obtaining a Landsat 5 TM-scene from 10 August 1987. Although the two scenes were from different years, the autocorrelation distance and the overall accuracy for individual classes were expected to be much higher because the use of two satellite scenes utilized the multispectral and multitemporal effect from the variation in spectral signatures in each individual cover class during the growing season.

The satellite data were geometrically corrected to the vegetation maps, enhanced using a histogram equalization procedure, and displayed on the computer monitor for interpretation and comparison with the ground measurements and the vegetation maps, which were scanned with a resolution equal to $10 \times 10 \mathrm{~m}$ in the field. Because both a detailed vegetation map and recent ground-truthing were available for most parts of the area covered by the SPOT-scene, a supervised classification was used. In four subareas, each covering $5 \times 5 \mathrm{~km}$ and distributed evenly over the lowland of Jameson Land, training sites of all known surface classes were selected containing at least 40 pixels from the largest and most homogeneous parts of the cover type. A maximum likelihood classifier was used to assign pixels to specific classes by comparing the reflectance value of each pixel with the spectral signatures of known training areas. The number of pixels used to generate spectral signatures for the known cover types ranged from 915 to 4188 . The separability of spectral signatures was measured statistically by calculating the autocorrelation distance ACD-values $>2$ indicates $<10 \%$ correlation between spectral signatures (Schowengerdt between spectral signatures (Schowengerdt 1983). A further 125 test areas were sampled to determine the overall accuracy for individual classes. To avoid mixed pixels, the 125 test areas were sampled from the central parts of larger vegetation units, representing the different cover types and an even distribution throughout the study area. The overall accuracy was expressed in a confusion matrix as the percentage of the cover type that had been classified correctly when compared to reference data (ground-truth) (Niblack 1985).

\section{Classification and Results}

\section{Photo-based mapping}

In the photo-based mapping, 14 vegetation classes and 4 non-vegetation classes were defined and 
used (Table 1). The vegetation analysis, which was carried out during the initial fieldwork, gives a quantitative description of the ground cover of the different vegetation classes.

In fen, hummocky fen and grassland mosses and vascular plants cover $90-100 \%$ of the ground. Vascular plants account for $5 \%$ to $20 \%$ of the plant cover. Cottongrass is characteristic of fen and hummocky fen. The latter also contains dwarf scrub and species from the moist dwarf scrub heath on the tussocks/hummocks. Grassland is less wet than fen and characterized by a number of graminoids.

Saltmarsh is only distributed along the coast on wet silty soil. The total ground cover is very variable. Graminoids (mainly Carex) cover about $25 \%$, and where the saline influence decreases, mosses cover $10-50 \%$.

Herb slope has a ground cover of $10-20 \%$ arctic willow, $15-30 \%$ forb, and $30-40 \%$ moss. Therefore it has a high total ground cover. However, late in the season the forbs dry out and the ground cover diminishes.

The total ground cover of vascular plants and mosses has been the primary criteria for subdividing the dwarf scrub heaths. Moist dwarf scrub heath has a ground cover of over $75 \%$ and is dominated by mosses. Dry dwarf scrub heath has a ground cover between 25 and $75 \%$ and is dominated by dwarf scrubs and mosses. Sparse dwarf scrub heath has a ground cover of less than $25 \%$ and is dominated by dwarf scrubs. Well-developed lichens are not a major ground cover component in Jameson Land, as they usually have a ground cover of less than $5 \%$. However, a greyblack surface coating on open humid soil termed "organic crust" consisting of prothallus of algae and lichens can cover up to $50 \%$ of the ground in dry dwarf scrub heath and sparse dwarf scrub heath.

Both fell-field and sand dune classes are dominated by bare ground. They contain no mosses and usually have a low percentage ground cover of vascular plants. However, in sheltered areas Sand dunes can have up to $20 \%$ plant cover.

The snowbeds are subdivided on the basis of the length of the snow-free period. In addition to the early and late snowbed, a willow-snowbed vegetation type with intermediate snow cover has been identified. In early snowbeds, moss dominates the ground cover ( $80 \%)$ and there is a high biodiversity of forbs. The willow-snowbeds occur on moist, often rather even ground, where the snowfree period is too short to provide for the dry dwarf scrub heath. Organic crust covers $80 \%$ of the ground in the late snowbeds and is also an important ground cover in the willow-snowbeds. However willow-snowbeds also have significant ground covers of mosses and arctic willow.

The interpretation accuracy of vegetation types from the aerial photos was assessed to be relatively high within a radius of $10-15 \mathrm{~km}$ from a ground-truthing site. In areas with uniform vegetation conditions, the accuracy may be high in a larger area; in areas with a complex or atypical vegetation the accurately interpreted area may be smaller. The delimitation of the main types (fen, grassland, scrub heath, copse, and snowbed) is more accurate than the subdivided types. This is especially true in areas with transition vegetation types.

\section{Satellite-based mapping}

The final cover classes and final result of the satellite based vegetation mapping in a subarea are shown in Table 2 and Fig. 3 with the photobased vegetation map. The ability of different satellite band combinations to distinguish the cover classes in a supervised maximum likelihood classification was tested using the final cover classes and constraints (Table 3 ). Not surprisingly the SPOT image from 8 September was less accurate than the Landsat image from 10 August, as the latter date was closer to the peak in green biomass. However, it was possible to make a classification using the SPOT data. The low overall accuracy of $71 \%$ was primarily caused by a confusion between fen and the moist dwarf scrub heath and confusions between the dwarf scrub heath classes. Using the TM data improved the overall accuracy of the classification considerably. The band combination TM 3, 4 and 5 were most suitable for making the classification. Bands 3 and 4 are known to be particularly useful in the recognition and classification of vegetated areas, while bands 5 and 7 are known to be useful in the case of moss and lichen dominated areas. TM band 5 proved to be the most important band, and it increased the accuracy from $81 \%$ to $85 \%$ when it was combined with SPOT and TM NDVI bands (SPOT 2,3 and TM 3,4). Using all bands from both SPOT and TM improved the classification accuracy by $3 \%$ compared to using the TM-bands alone, and this gave the highest overall accuracy of $86 \%$. 
Table 2. Cover classes of the photo-based and the satellite-based mappings with constraints used in the satellite-based mapping

\begin{tabular}{llll}
\hline Cover class & $\begin{array}{l}\text { Photo- } \\
\text { based } \\
\text { mapping }\end{array}$ & $\begin{array}{l}\text { Satellite- } \\
\text { based mapping }\end{array}$ & Constraints \\
\hline Fen & M1 & M1 + G1 \\
Hummocky fen & M2 & M2 \\
Grassland & G1 & omitted \\
Salt marsh & G2 & omitted \\
Copse & T & S1 \\
Early snowbed & S1 & S2 \\
Late snowbed & S2 & S3 \\
Willow snowbed & S3 & omitted \\
Herb slope & H2 & H3 \\
Moist dwarf scrub & H3 & H4 \\
Dry dwarf scrub & H4 & H5 \\
Sparse dwarf scrub & H5 & H7 \\
Fell-field & H7 & \\
Sand dune & H8 & I1 & I1 + H8 \\
Bare ground & I4 & I4 \\
River bed & I5 & I5 \\
Ice or snow & L & L \\
Pond or lake & & M (new) \\
Sea & & NDVI & 115 \\
\hline
\end{tabular}

Table 3. Accuracy of the supervised classification using different combinations of the satellite spectral bands.

\begin{tabular}{lrl}
\hline Bands & Number of bands & \% Accuracy \\
\hline SPOT all + TM all & 10 & 86 \\
SPOT 2,3 + TM 3,4,5 & 5 & 85 \\
SPOT 2,3 + TM 3,4 & 4 & 81 \\
TM all & 7 & 83 \\
TM 3,4,5 & 3 & 81 \\
SPOT all & 3 & 71 \\
\hline
\end{tabular}

In the process of conducting a supervised classification using training areas from the photobased mapping, three cover classes were omitted and in two instances two classes were merged together (Table 2).

The vegetation classes copse and salt marsh were omitted because they were difficult to classify. They have a very local distribution and comprise much less than $0.1 \%$ of the total area in the satellite-based mapping. It was therefore not possible to select a homogeneous training class of a satisfactory size in this part of Jameson Land. The copse class has a species composition very similar to that of moist dwarf scrub heath, but its composition is defined as being dominated by dwarf scrubs taller than $20 \mathrm{~cm}$. Salt marsh, which provides important feeding areas for geese, can be manually identified and added subsequently to the main classification because it only occurs near the shoreline, where it is often misclassified as fen. Herb slopes were also omitted. Although their total cover is small, they have a high biodiversity and are ecologically important as feeding areas for muskoxen because of their high productivity and biomass. However, since herb slopes seldom comprise more than $100 \mathrm{~m}^{2}$ and very few have the size of a pixel (SPOT $400 \mathrm{~m}^{2}$, Landsat $900 \mathrm{~m}^{2}$ ), it is unreasonable to try to map them using satellite data. Herb slopes occur as part of the vegetation mosaic with a high biodiversity consisting of early snowbed, moist dwarf scrub heath and fen. Herb slopes has been classified as one of these three classes in the

Fig. 3. Vegetation map of the area surrounding the mouth of Draba Sibirica Elv. The photo-based mapping is to the left and satellite-based map is to the right. Width of the area shown is approximately $2.5 \mathrm{~km}$, the area is indicated on Fig. 1 . The codes the cover classes are explained in Tables 1 and 2 . It is low-tide in the satellite-based map.

Fig. 4. Satellite-based vegetation map of the $3200 \mathrm{~km}^{2}$ study area on Jameson Land. The study area is indicated on Fig. 1 . The codes for the cover classes are explained in Tables 1 and 2 . 


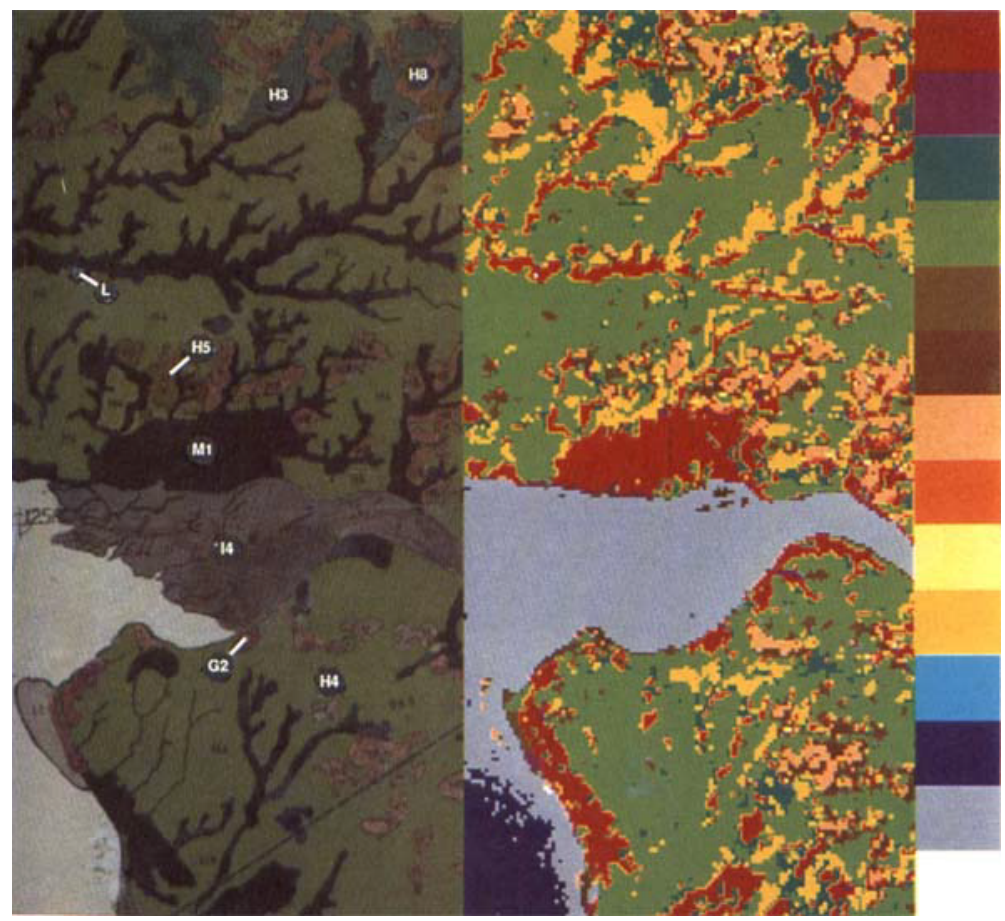

M 1 (G1)

M 2

H 3

H 4

H 5

H 7

I $1($ H 8)

S 1

S 2

S 3

L

F

I 4

I 5

Fig. 3

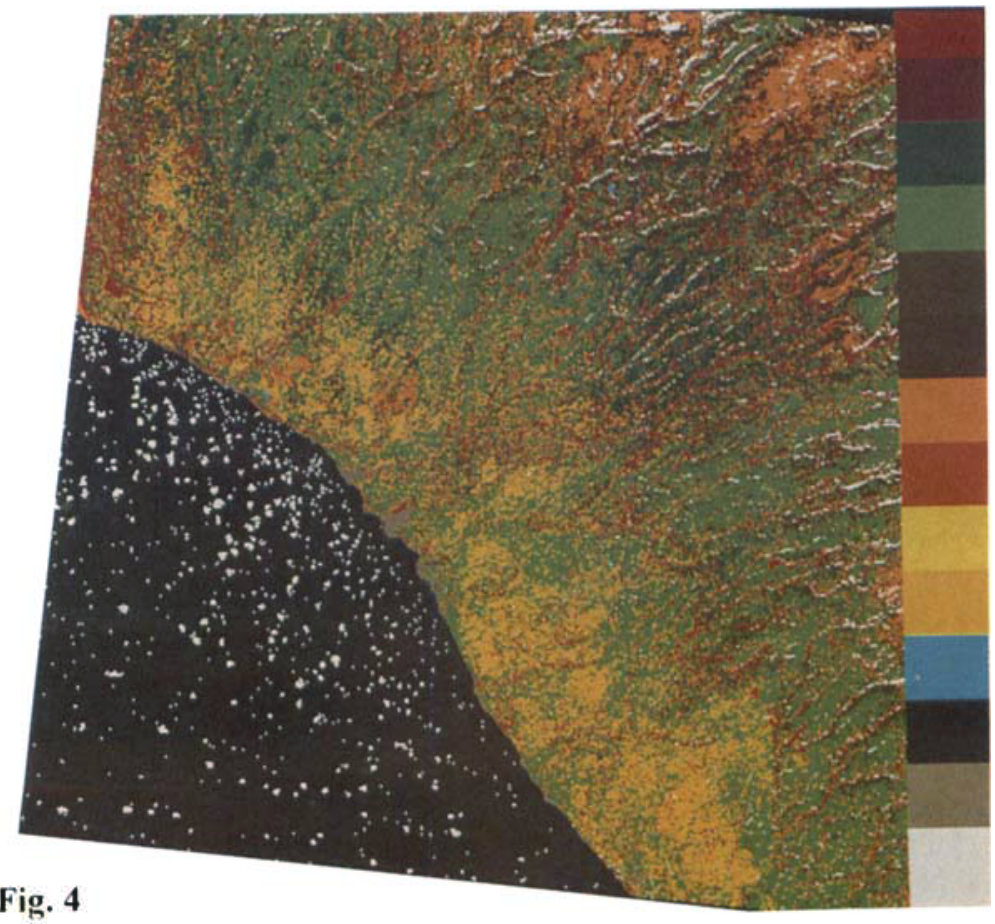

M 1 (G1)

M 2

H 3

H 4

H 5

H 7

I 1 (H 8)

S 1

S 2

S 3

L

F

I 4

I 5 
supervised classification, when omitted as a training class.

The ability of the satellite data to distinguish grassland from fen was inadequate and the two classes were therefore merged. The two classes are very similar as they both have nearly $100 \%$ moss cover with approximately $10-15 \%$ cover of protruding graminoids. The graminoids are dominated by sedges and cotton grass in the fen class and by grasses in the grassland. Grassland was put in the fen class being the minor of the two, covering just $1-2 \%$ of the area.

Sand dunes primarily constitute a geomorphological class for sandy wind-eroded areas near the coast. The vegetation is sparse with low biodiversity, consisting mainly of dwarf scrubs. The total vegetation cover seldom reaches $20 \%$, and there are unvegetated windbreaks of several thousands $\mathrm{m}^{2}$. It was not possible to distinguish the sand dune class from the unvegetated bare ground class; the minor sand dune class was therefore included in the bare ground class.

Having decided the cover classes, the separation was optimized by the use of two NDVI constraints (Table 2) because NDVI (Normalised Difference Vegetation Index) has a high correlation with the soil coverage by the green biomass. The dwarf scrub heath classes are in nature often more like a continuum, in which they merge unobtrusively, slowly grading into each other. In the photo-based vegetation mapping, the border between moist and dry dwarf scrub heath was defined as $75 \%$ vegetation cover (Table 1). In the satellite-based mapping we improved the classification accuracy with the constraint that NDVI in the moist dwarf scrub heath had to exceed 0.15. Fell-field and sparse dwarf scrub heath likewise merge into the bare ground class as the vegetative cover diminishes. The separation was improved with the constraint that bare ground had to have a NDVI of less than 0.05 .

Using all 10 bands of the TM and SPOT images the separability of the cover classes was tested by use of a confusion matrix. The characteristic nonvegetation areas were classified with an accuracy close to $100 \%$ (sea, lake, river-bed and snow and ice). The snow and ice were classified with the TM image only because the snow cover (snow patches) naturally had very different magnitudes on the two images from different seasons in different years. Because of the multitemporal effect when using satellite data from both wet summer and dry autumn, the snowbed vegetation types (early-, late- and willow snowbed) were all classified with a very high accuracy $(>95 \%)$. However we sampled the test areas in central parts of vegetation units so the accuracy measurement avoided the problems associated with mixed pixels in border areas between vegetation units. In Fig. 3, willow snowbed pixels lining the transition zones between fen and dry dwarf scrub heath vegetation units illustrate the problem. Some of these willow snow-patch pixels are undoubtedly correctly classified, but they did not constitute a vegetation unit large enough to be mapped during ground-truthing in the photo-based mapping (selective resolution).

The confusion matrix for cover types classified with less than 95\% accuracy is given in Table 4 . $78 \%$ of the pixels in the fen test areas have been correctly classified, $10 \%$ have been misclassified as hummocky fen, and $11 \%$ misclassified as moist dwarf scrub heath. Likewise $5 \%$, of the hummocky fen pixel and 5\% of the moist dwarf scrub heath pixels have been misclassified as fen. These misclassifications, for the most part, reflects broad transition zones between the vegetation classes.

The fell-field, which has the lowest classification accuracy $(67 \%)$, has $31 \%$ of the pixels misclassified as sparse dwarf scrub heath, while the sparse dwarf scrub heath has $11 \%$ of the pixels misclassified as fell-field. This classification problem is caused by both types having a low vegetation cover which produces insufficient reflection from the vegetation to allow a distinction between the two. Furthermore, the two types have a gradually changing rather than sharply defined borderline.

Fig. 4 shows the final result of the satellitebased vegetation mapping for the $3200 \mathrm{~km}^{2}$ area covered by both the SPOT and the Landsat images, while Fig. 5 shows the relative distribution of the vegetation classes in the same area. Dry dwarf scrub heath covered $31 \%$ of the area, while moist dwarf scrub heath covered $15 \%$. Fen (incl. grassland) and hummocky fen covered $14 \%$ of the area mainly along lakes and rivers. Dry, sparse dwarf scrub heath and fell-field covered $11 \%$ and $9 \%$ respectively, mainly in the inland parts of the area, while snowbeds covered $10 \%$ being distributed along valleys coastal areas.

\section{Discussion}

In this study we have produced a digital map using 
Table 4. Confusion matrix showing percentage reference area pixels correctly classified (bold) and percentage classified as other classes. For clarification, vegetation types with more than $95 \%$ of pixels in reference areas correctly classified have been omitted from the table (early snowbed, late snowbed, willow snowbed, ice and snow, river, lake and sea).

\begin{tabular}{lrlclcrrr}
\hline $\begin{array}{l}\text { Vegetation classes } \\
\text { Reference areas }\end{array}$ & Fen & $\begin{array}{l}\text { Hummocky } \\
\text { fen }\end{array}$ & Moist dwarf scrub & $\begin{array}{l}\text { Dry dwarf } \\
\text { scrub }\end{array}$ & $\begin{array}{l}\text { Sparse } \\
\text { dwarf scrub }\end{array}$ & Fell-field & $\begin{array}{l}\text { Bare } \\
\text { ground }\end{array}$ & $\Sigma \%$ \\
\hline Fen & $\mathbf{7 8}$ & 10 & 11 & 1 & 0 & 0 & 0 & 100 \\
Hummocky fen & 5 & $\mathbf{9 5}$ & 0 & 0 & 0 & 0 & 0 & 100 \\
Moist dwarf scrub & 5 & 0 & $\mathbf{9 0}$ & 2 & 0 & 0 & 0 & 97 \\
Dry dwarf scrub & 2 & 0 & 2 & $\mathbf{8 6}$ & 7 & 1 & 0 & 98 \\
Sparse dwarf scrub & 0 & 0 & 0 & 5 & $\mathbf{8 0}$ & 11 & 5 & 96 \\
Fell-field & 0 & 0 & 0 & 0 & 31 & 67 & 2 & 100 \\
Bare ground & 0 & 0 & 0 & 0 & 6 & 2 & $\mathbf{9 2}$ & 100 \\
\hline
\end{tabular}

a supervised classification based on the spectral signatures of 10 satellite sensor bands from two seasons and ground-truthed training areas for supervision. The digital map has a fairly high accuracy (86\%, Tables 2 and 3 ) in the reproduction of the vegetation classes of field-verified photo-based maps. Geometric incongruence can cause inaccuracy because the photo-based maps were based on aerial photos which were not geometrically corrected. However, we avoided border areas and sampled training and test areas from central parts of larger vegetation units as far as possible. Vegetation classes occurring in small units are more liable to be affected by geometric incongruence because more pixels from border zones have been used in the analysis. The sampling procedure also minimized inaccuracy originating from the subjective element in the delineation of vegetation units in the photo-based mapping.

We estimate the degree of accuracy of the photo-based map outside the field-verified areas to be generally the same as that of the satellitebased map. On the whole, the photo-based map has larger vegetation units with a more homogeneous and less complex texture than the satellite based-map. However in the latter, it was necessary to simplify the map by reducing the

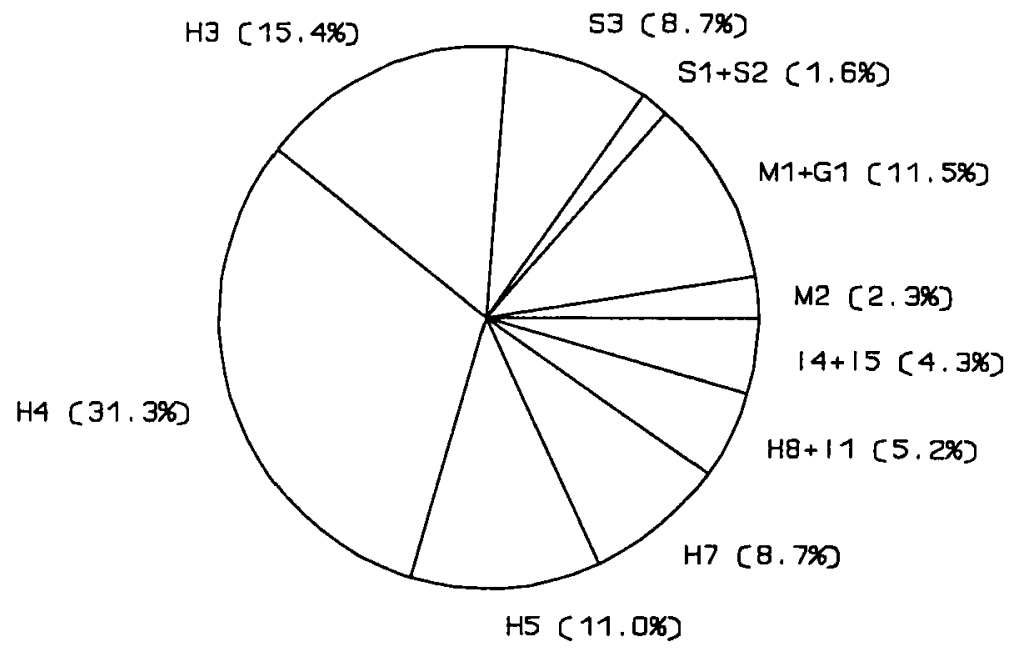

Fig. 5. Relative distribution of the cover classes in the satellite-based map in the $3200 \mathrm{~km}^{2}$ study area. The codes for the cover classes are explained in Tables 1 and 2. 
number of cover types from the original 14 vegetation classes and 4 non-vegetation classes to 9 vegetation classes and 4 non-vegetation classes.

In the satellite-based mapping's ability to distinguish predefined vegetation types we have encountered four constraints:

1. It is not possible to separate vegetation classes using the vegetation cover if the classes are hardly vegetated and the spectral signature is dominated by bare ground. Large areas in the sand dunes are unvegetated and the class could not be distinguished from bare ground.

2. It is not possible to map vegetation classes which occur in units of subpixel size. The herb slope class, which rarely covers an area approaching the size of a pixel, had to be omitted.

3 . It is not possible to distinguish vegetation classes if there is no difference in the spectral signature, even though the species composition differs. Neighbouring vegetation classes which did not differ in spectral signatures even though they were different in species composition, were merged (grassland to fen).

4. Satellite-based mapping does not produce a sharp border between vegetation units which have broad transition zones in nature. The mixing of pixels in the transition zones between e.g. the different types of dwarf scrub heath makes the digital map heterogeneous in texture. However it reflects the natural conditions better than a photobased map where there is a subjective element in delineation.

The simplification of vegetation classes in the satellite-based classification can partly be overcome by manual readjustments using topographical information (e.g. salt marsh and sand dunes are only in the coastal zone) in combination with extended ground-truthing. The topographic information could also be applied by incorporating a digital terrain model during the classification.

Herb slope is the most problematic vegetation class in the satellite based mapping because the units are often of subpixel size. Reliable classification requires satellite data with a better spatial resolution than is available today. The herb slopes are pinpointed in the photo-based mapping because the aerial photos have a higher spatial resolution (estimated to $1 \times 1 \mathrm{~m}$ ) than satellite data, although the vegetation units of satellitebased mapping are generally smaller than in the photo-based mapping.

Stow et al. (1989) measured the spatial scales of vegetation community units in an area of arctic tundra in Alaska also mapped by Walker et al. (1989). They found that most vegetation units are small, characterized by spatial scales of less than $45 \mathrm{~m}$, and approximately half of the vegetation units in at least one-dimension would not be resolved by the SPOT sensor with its nominal $20 \mathrm{~m}$ spatial resolution. After further analysis, including the examination of colour infrared aerial photographs (digitized to 1 metre pixels), Stow et al. (1993) found that a spatial resolution of at least $10 \mathrm{~m}$ is required to adequately sample the spatial variability of the tundra landscape.

These results from the Alaskan tundra fit well with our results from the tundra of eastern Greenland. Even though a fine-scaled vegetation map may not be needed for practical purposes, the fin-scaled vegetation mosaic of the arctic tundra demands this high resolution if important vegetation classes are not to be missed.

In the photo-based mapping of Jameson Land, vegetation classes were mapped manually with varying spatial resolution adapted to average unit size. It was an expensive and laborious process which took 4 years including field-work. The satellite data processing took approximately $1 / 2$ year. Satellite data from a remote area are less expensive (Landsat TM $1.20 \mathrm{dkr} \cdot / \mathrm{km}^{2}$; SPOT $5.50 \mathrm{dkr} . / \mathrm{km}^{2}$ ) to acquire than aerial photos $\left(70 \mathrm{dkr} \cdot / \mathrm{km}^{2}\right)$ so long as the aerial photos are not available from archive sources. Both methods require ground-truthing, but due to the objective character of the satellite based mapping, we estimate less ground-truthing is required when multitemporal data including data on the peak in green biomass are available.

Vegetation maps of Jameson Land were made with the purpose of identifying areas with vegetation types which were either especially sensitive to being traversed by vehicles and winter seismic equipment, or important as feeding areas for muskoxen and geese. The importance of the satellite-based mapping deficiencies in distinguishing predefined vegetation classes depends on the purpose of the vegetation mapping. In our study the initial vegetation class definitions were essentially floristic, following botanical tradition as were the studies by Walker et al. (1989) and Stow et al. (1989). This results in a basic vegetation mapping which can be used for many purposes e.g. ecological modelling in different wildlife studies, impact assessment and environmental regulation. It can however be necessary 
to adapt the photo-based vegetation classes to the remote sensing technique because the photobased vegetation classes are not only defined by their dominant ground cover, which can be measured from the satellite. Many remote sensing vegetation studies focus on a specific purpose during the process of defining the cover types: Peace (1991) and Ferguson (1991) mapped the muskox habitat; Matthews (1991) mapped the bison habitat; and Johansen \& Tømmervik (1990) mapped the reindeer habitat. By focusing on one purpose it is easier to decide on how to simplify the cover classes which may be necessary in order to obtain a high accuracy classification based on the available data.

Peace (1991) mapped the muskox habitat on Devon Island $(71.30 \mathrm{~N})$ with SPOT satellite data from 24 July. A supervised classification resulted in 8 cover classes which was simplified to 5 distinct cover classes. There were two types of sedge meadows: the hummocky sedge/moss meadow and the frost boil sedge/moss meadow. They had a considerable spectral overlap in the near-infrared band, were hard to separate and were misclassified in some locations.

Ferguson (1991) mapped the muskox habitat on Banks Island with TM satellite data from 5 August. He made a supervised classification with 7 vegetation classes, and a snow and ice class and a water body class. He obtained an overall classification accuracy of $88 \%$. Discrimination between two of the classes, dwarf scrub tundra and hummocky tundra, was however difficult, and the hummocky tundra tended to merge into the dwarf scrub tundra. As in our study, Ferguson concluded that Landsat data alone are probably insufficient to depict vegetation types having discontinuous plant cover because the background reflectance from soil or exposed rock often dominates the reflectance from the vegetation.

Our study has shown that it is important to have satellite data with a high spatial, spectral and radiometric resolution. The study shows how the spectral differences of the vegetation cover types diminish from the 10 August, close to the peak in green biomass, to 8 September, when autumn has come to the Arctic. However, it is clear that the multitemporal data have made an improvement. In comparison with the photobased mapping, the satellite based mapping is generally an advantage when mapping large areas because it is fast, objective and less expensive, but it still lacks the spatial resolution to map all important cover classes. Detailed ground-truth data are important for the training areas, and the interpretation of the satellite data may be improved with in-situ spectral measurements of ground cover types (Stow et al. 1993). During the field seasons of 1992 and 1993, detailed spectral radiance data from hand-held radiometers were sampled (Fig. 2) in order to quantify and analyse the spectral, spatial and temporal variability of solar radiation reflected from the arctic tundra vegetation. The results will be used in the future to improve the separability of the cover types and the accuracy of the mapping of tundra vegetation in East Greenland.

Acknowledgements. - The authors would like to thank C. Bay (Greenland Botanical Survey) and S. Holt (Carl Bro as) for their help with this study and their valuable comments on the draft manuscript.

\section{References}

Bay, C. \& Holt, S. 1986: Vegetationskortlagning af Jameson Land 1982-1986. Grønlands Fiskeri og Miljøundersøgelser, Grønlands Botaniske Undersøgelser. 40 pp.

Boertmann, D. 1991: Distribution and numbers of moulting non-breeding geese in Northeast Greenland. Dansk Orn. Foren. Tidsskr. 85, 77-88.

Boertmann, D., Forchammer, M., Olesen. C. R., Aastrup, P. \& Thing, H. 1992: The Greenland muskox population status 1990. Rangifer 12, 5-12.

Ferguson, R. S. 1991: Detection and Classification of Muskox Habitat on Banks Island, N.W.T., Canada, Using Landsat Thematic Mapper Data. Arctic 44 (Supp. 1), 66-74.

Folving, S. 1986: Mapping of vegetation types in S.W. Greenland. ESA/EARSeL Symposium on Europe from Space, Lyngby, DK, ESA SP-258, 239-243.

Hansen, B. U. \& A. Mosbech, 1994: Use of NOAA-AVHRR data to monitor snow cover and spring meltoff in wildlife habitats on Jameson Land, East Greenland. This volume.

Holm, J., Olesen, H. H., Sandholt, I., Andersen, H. S. \& Rasmussen, K. 1988: CHIPS User's Guide. Vers. 2.0. Institute of Geography, University of Copenhagen.

Holt, S. \& Bay, C. 1983: Effects of All Terrain Cycle (ATC) on Fen Vegetation in Jameson Land, NE Greenland. Gronlands Fiskeri-og Miljøundersøgelser, Grønlands Botaniske Undersøgelser, 1-9.

Johansen, B. \& Tømmervik, H. 1990; Mapping Winter Grazing areas for Reindeer in Finmark County, Northern Norway, Using Landsat 5-TM Data. Remote Sensing Science for the Nineties. IGARSS, 613-616.

Kamarkova, V. \& Webber, P. J. 1980: The low arctic vegetation maps near Atkasook, Alaska. Arctic and Alpin Research $12(4), 447-472$.

Madsen, J. \& Mortensen C. E. 1985: Habitat exploitation and interspecific competition of moulting geese in East Greenland. IBIS I29, 25-44.

Mosbech, A. \& Glahder C. 1990: Moniteringen af gæs i Jameson Land 1983-1989. Grønlands Miljøunders $\emptyset$ gelser. $50 \mathrm{pp}$. 
Matthews, S. B. 1991: An Assessment of Bison Habitat in the Mills/Mink Lakes Area, N.W.T., Using Landsat Thematic Mapper Data. Arctic 44, (Supp. 1), 75-80.

Niblack, W. 1985: An Introduction to Digital Image Processing. Copenhagen, Strandberg. 215 pp.

Pearce 1991, C. M. 1991: Mapping Muskox Habitat in the Canadian High Arctic with SPOT Satellite Data. Arctic 44 (supp. 1), 49-57.

Olesen, C. R. 1990: Bestandsudvikling og økologi for muskoxokser i Angajaartorfiup Nunaa, Vestgrønland. Teknisk rapport, Grønlands Hjemmestyre, Miljø-og Naturforvaltningen 16. p. 85.

Spjelkavik, S. \& Elvebakk A. 1987: Mapping winter grazing areas for reindeer on Svalbard using Landsat Thematic Mapper Data. Proceedings of a Workshop on "Earthnet Pilot Project on Landsat Thematic Mapper Applications". Frascati. Pp. 199-206.

Schowengerdt, R. A. 1983: Techniques for image processing and classification in remote sensing. New York, Academic Press. 249 pp.

Stow, D., Burns, B. \& Hope, A. 1989: Mapping Arctic tundra vegetation types using digital SPOT/HRV-XS data: a preliminary assessment. Int. J. Remote Sensing 10, 1451-1457.
Stow, D., Burns, B. \& Hope, A. 1993: Spectral, spatial and temporal characteristics of Arctic tundra reflectance. Int. J. Remote Sensing 14, 2445-2462.

Thing, H., Klein, D. R., Jingfors, K. \& Holt, S. 1987: Ecology of muskoxen in Jameson Land, Northeast Greenland. Holarctic Ecology 10(2), 95-103.

Thompson, D. C., Klassen, K. H. \& Cihlar, J. 1980: Caribou habitat mapping in the southern district of Keewatin, N.W.T.: An application of digital Landstat data. J. Appl. Ecol. 17, 125-138.

Walker, D. A. \& Acevedo, W., 1987: Vegetation and a Landsatderived land cover map of the Beechey Point Quandrangle, Arctic Coastal Plain, Alaska. CRREL Report 87-5. 67 pp.

Walker, D. A., Binnian E., Evans, B. M., Lederer, N. E., Nordstrand, E. A. \& Petersen, G. W. 1989: Terrain, vegetation, and landscape evolution of the R4D research site, Brooks Range Foothills, Alaska. Holarctic Ecology 12(3), 232-262.

Ødegard, H. \& Øritsland, N. 1980: Mapping polar vegetation at Spitsbergen by use of Landsat. Final report. Rapport MAB/IBM. $69 \mathrm{pp}$. 